\title{
The Rabbi's Position in a Jewish Community of the Kingdom of Poland in the First Half of the Nineteenth Century: The Controversy over Zachariasz Weingott in Częstochowa*
}

\begin{abstract}
In the nineteenth century, Częstochowa was home to one of the largest Jewish communities in the Kingdom of Poland, but for most of this time it had no communal rabbi approved by both the community and the state authorities. The first such rabbi, Zachariasz (Yisakhar) Weingott, was elected in 1822, but a mere two years later he was forced to resign. The attempts to elect a new rabbi led to major social conflicts and continued to fail, while the rabbinical duties were executed by unofficial rabbis (Jakub Brass and Mojżesz Majzel). It was only in 1839 that Weingott was re-elected to the post of the rabbi and held that position until his death in 1852 . As it seems, the conflict was animated by a competition between adherents of modernization and the traditional segments of the Jewish community in Częstochowa, including the Hasidim. As such, it was an expression of a typical communal conflict that plagued east-European Jewish communities of the nineteenth century. What seems of special interest, however, is that a detailed analysis of the Częstochowa case makes it possible to trace other-familial and businessconnections, behind the well-known ideological divisions, quite often transcending traditional divisions into modernist and traditionalist camps.
\end{abstract}

Keywords: rabbis, the Kingdom of Poland, Częstochowa, Zachariasz (Yisakhar) Weingott, modernization, Orthodoxy, Hasidism.

Polish edition: Janusz Spyra, "Miejsce rabina w gminie żydowskiej w Królestwie Polskim w I połowie XIX wieku. Spór o Zachariasza Weingotta w Częstochowie," Studia Judaica 19 (2016), 1: 157-186.

The special edition of the journal Studia Judaica, containing the English translation of the best papers published in 2016, was financed from the sources of the Ministry of Science and Higher Education for promotion of scientific research, according to the agreement 508/P-DUN/2016. 
Due to their religious authority, rabbis have always played a very important role in Jewish society—both in real and symbolic terms. No great Jewish community can exist for long without a rabbi; yet paradoxically, rabbis are not necessary at all times, especially those who serve as official community rabbis. ${ }^{1}$ Any follower of Judaism can ask for the opinion of any rabbinical authority, and the Jewish system of religious education provides many people with rabbinical competencies. The majority of these people perform auxiliary religious functions, e.g. as assistant rabbis or members of Jewish courts (i.e. beth din). ${ }^{2}$

The role of rabbis in Jewish society has long been a subject of research, ${ }^{3}$ which only recently has expanded beyond the contributions of individual rabbis to the development of Jewish theology. In practice, their position has depended on the intricate network of connections and dependencies determined by the communities that employ them, including lay leaders. ${ }^{4}$ Also important in this regard have been the expectations of the (formerly feudal) state, which grants rabbis some of their judicial and orderly powers. In this respect, great changes took place in the nineteenth century during the formation of modern state bodies, which sought to control all spheres of public life. In Western Europe-and later in Central Europe-the state administration tried to install rabbis as supervised state employees, e.g. as record keepers. This coincided partially with the views of Haskalah supporters, for whom the range of duties of "modern" rabbis should be

${ }^{1}$ Shaul Stampfer, Families, Rabbis and Education: Traditional Jewish Society in Nineteenth-Century Eastern Europe (Oxford, 2010), 277-282. For a general overview see Simon Schwarzfuchs, A Concise History of the Rabbinate (Oxford 1993).

${ }^{2}$ For more on the role of rabbis in traditional communities, see, e.g., Anna MichałowskaMycielska, The Jewish Community: Authority and Social Control in Poznan and Swarzędz 1650-1793 (Warsaw, 2015), wherein further literature is also listed; see also Adam Teller, "Rabbis without a Function? The Polish Rabbinate and the Council of Four Lands in the Sixteenth to Eighteenth Centuries," in Jack Wertheimer (ed.), Jewish Religious Leadership: Image and Reality (New York, 2004), 1: 371-400; id., "Tradition and Crisis? EighteenthCentury Critiques of the Polish-Lithuanian Rabbinate," Jewish Social Studies 17 (2011), 3: 1-39; Rafał Żebrowski, "O rabinach słów kilka," in Zofia Borzymińska, Marta RzepeckaAleksiejuk, Rafał Żebrowski (eds.), Miasto bez rabina nie może istnieć: Rabini, podrabini i kandydaci na rabinów w guberni warszawskiej w latach 1888-1912 (Warsaw, 2012), 13-21.

${ }^{3}$ For example, Julius Carlebach (ed.), Das aschkenasische Rabbinat: Studien über Glaube und Schicksal (Berlin, 1995); as well as Carsten L. Wilke, "Einleitung," in Michael Brocke, Julius Carlebach (eds.), Biographisches Handbuch der Rabbiner [henceforth: BHR], part I/1-2: Carsten L. Wilke (ed.), Die Rabbiner der Emanzipationszeit in der deutschen, böhmischen und großpolnischen Ländern 1781-1871 (Munich, 2004), 34-118.

${ }^{4}$ Andreas Brämer, Rabbiner und Vorstand: Zur Geschichte der jüdischen Gemeinde in Deutschland und Österreich 1808-1871 (Vienna-Köln, 1999). 
similar to those of Christian clergymen. ${ }^{5}$ Rabbis were therefore to acquire not only a Talmudic education, but a general lay education as well. ${ }^{6}$

The authorities of the Kingdom of Poland also sought to transform Jewish communities into administrative districts in order to control their members. For this purpose, "synagogue supervisory bodies" (dozory bóżnicze) were created under the oversight of the state to replace kahals in $1822 .{ }^{7}$ Great emphasis was put on the education of rabbis, who-in the opinion of the authorities-had thus far kept the Jewish population in the dark, and now had to contribute to its "civilization." "In 1826, the School of Rabbis was established in Warsaw, whose graduates were tasked with "moral reform of the Jews." It existed until 1863, but none of its graduates were ever employed as a community rabbi in the Kingdom of Poland. ${ }^{9}$

It is therefore no coincidence that the appointment of community rabbis and the determination of their competencies were hotly debated. Many writings appeared on the subject, most frequently in the context of the rivalry between Haskalah supporters and traditionalists, or that between traditionalists and Hasidim. The motives for appointing rabbis, and thus the conflicts that ensued, were very diverse. These conflicts, which are significant for today's researchers, were not always so important for the interested parties, especially in small or remote Jewish communities. Here, decisions were made by local administrative units. An important role in these units was played by both the personal qualities of candidates and the reputations of their teachers, as well as family ties, which were often clientele-like, and which were reinforced by complicated economic relationships. Exactly how each community functioned was a result of various factors, which were always reflected in the position of the rabbi, who was subject not only to religious law, but state law, pressure from government officials, and the often discrepant expectations and interests

${ }^{5}$ Cf. Andreas Brämer, “'Der Rabbiner als Geistlicher': Eine Kontroverse aus der Zeit der Emanzipation," in Michael Brocke, Aubrey Pomerance, Andrea Schatz (eds.), Neuer Anbruch: Zur deutsch-jüdischen Geschichte und Kultur (Berlin, 2001), 263-277.

${ }^{6}$ Carsten Wilke, "Den Talmud und den Kant": Rabbinerausbildung an der Schwelle zur Moderne (Hildesheim, 2003).

${ }^{7}$ See also Jakób Kirszrot, Prawa Żydów w Królestwie Polskiem: Zarys historyczny (Warsaw, 1917), 43-77.

${ }^{8}$ Marcin Wodziński, “Civil Christians': Debates on the Reform of the Jews in Poland, 1789-1830," in Benjamin Nathans, Gabriella Safran (eds.), Culture Front: Representing Jews in Eastern Europe (Philadelphia, 2008), 46-76.

9 See also Antony Polonsky, "Warszawska Szkoła Rabinów: Orędowniczka narodowej integracji w Królestwie Polskim," in Michał Galas (ed.), Duchowośc żydowska w Polsce (Kraków, 2000), 287-308. 
of the community that employed him. ${ }^{10}$ As Stampfer wrote, the costs of maintaining any institution-in this case the rabbinate-must match its utility, including with respect to the peace and order in a given community, which is what determines the authority of its head rabbi. ${ }^{11}$

One example is the decades-long dispute over the position of community rabbi in Częstochowa. In the nineteenth century, one of the largest Jewish communities in the Kingdom of Poland was formed there. Previously, the Jews had been restricted access to the city by the townspeople. By the time the Polish-Lithuanian Commonwealth ended, there were a hundred Jews living in Stara Częstochowa [Old Częstochowa] who, although they belonged to the neighboring kahal in Janów, would meet in the room of the rabbi's assistant for prayer. ${ }^{12}$ There was no lack of persons with rabbinical competencies among them. Two likely members of the beth din in Częstochowa at the end of the eighteenth century were Rabbi Abraham from Częstochowa (the son-in-law of Dan, rabbi of Ciechanów) ${ }^{13}$ and Arie Czenstochow, who was mentioned in 1796. Records from Piotrków list Dawid Izaak as the chairman of the rabbinical court in Częstochowa. He subsequently served as the head of the rabbinical court in Piotrków, and authored a commentary entitled Bet David, published in 1807. ${ }^{14}$ Moreover, born in Częstochowa was Gedalja Tiktin (1808-1886), who later became the provincial rabbi of Prussian Silesia. ${ }^{15}$ Due to the size and heterogeneity of its Jewish community, Częstochowa seems a good place to analyze phenomena which also occur in other regions.

${ }^{10}$ Especially in places where the election of rabbis is unregulated, as was the case in the Kingdom of Poland. Cf. Marcin Wodziński, Wtadze Królestwa Polskiego wobec chasydyzmu: $Z$ dziejów stosunków politycznych (Wrocław, 2008), 93. For general information, see Stampfer, Families, 280-292.

${ }^{11}$ Ibid., 289.

${ }^{12}$ Kazimierz Rędziński, "Początki żydowskiej gminy wyznaniowej w Częstochowie (1808-1862)," in Zbigniew Jakubowski, Stanisław Podobiński (eds.), Z dziejów Żydów w Częstochowie (Częstochowa, 2002), 127-136.

${ }^{13}$ Louis Lewin, "Ein Judentag aus Süd- und Neuostpreußen," Monatsschrift für Geschichte und Wissenschaft des Judentums N.F. 23 (1915), 5: 296, n. 1.

${ }^{14}$ Died in 1818 or 1821. See Yakov Shatzky, "Jews in Czenstochowa up to the First World War," in Raphael Mahler (ed.), Tshenstokhover Yidn (New York, 1947), 28-29. I used the English translation by Gloria Berkenstat Freund, available online as part of the Yizkor Book Project, http://www.jewishgen.org/Yizkor/czestochowa1/Czestochowa1.html\#TOC3 [retrieved: 29 July 2016].

${ }^{15}$ Biographical notes of Gedalja Tiktin, his father Salomon, and his grandfather Abraham in BHR I/2, pp. 856-859. 


\section{Community Beginnings in Częstochowa and the First Election of Zachariasz Weingott}

Changes took place after the second partition of Poland in 1793, when Częstochowa became part of Prussia, and Janów remained within the Polish-Lithuanian Commonwealth. The new authorities did not want their Jewish subjects to be administratively dependent on another country, so they ordered the Częstochowa Jews to form a separate community, and granted them the right to build a synagogue and cemetery. The Jews, however, were in no rush to do so. ${ }^{16}$ It was not until 1805 that they began construction of the synagogue, and they appear to have finished it in $1808 .{ }^{17}$ In that same year, Jakub ben Eliezer Lewi was appointed chairman of the beth din, and representative of the kahal. Yakov Shatzky writes that Lewi was a "spiritual person," and according to D. H. Asz he was the first local rabbi. ${ }^{18}$ Also referred to as Leywa, Lewi appears regularly in public registers as a witness-most frequently referred to as "syndicus vel kahal syndic," ${ }^{19}$ but never as rabbi. He died in Częstochowa on 12 December 1829 at the age of $72 .{ }^{20}$ It is likely that he was the above-mentioned rabbi's assistant at the end of the eighteenth century.

The independence of Częstochowa Jews was related to a gradual increase in their number, ${ }^{21}$ and consisted in their construction of a cemetery, prayer house, and later a synagogue. The issue of the rabbi is not addressed in correspondence from Prussia and the Duchy of Warsaw; and

${ }^{16}$ Archiwum Główne Akt Dawnych w Warszawie [Central Archives of Historical Records in Warsaw; henceforth: AGAD], collection: Dyrektorium Prus Południowych [Department of South Prussia], call no. VI-377.

${ }^{17}$ AGAD, collection: Centralne Władze Wyznaniowe Królestwa Polskiego [Central Religious Authorities of the Kingdom of Poland; henceforth: CWW], call no. 1542, p. 249.

${ }^{18}$ D.[awid] H.[ersz] Asz, "Di geshikhte der yudisher kehila in Tshenstokhav," Naye Tsaytung (1914), 1: 11-12. Janusz Spyra, "Żydowski ksiądz? Rabin w społeczności żydowskiej Częstochowy," Częstochowskie Teki Historyczne 4 (2013/14), 140, identifies him as Jakub Brass. In fact, these are two different people.

${ }^{19}$ Starting from 1808 in the records of the Roman Catholic Parish of St. Zygmunt in Częstochowa (Archiwum Państwowe w Częstochowie [State Archives in Częstochowa; henceforth: APCz], collection: Akta Stanu Cywilnego Parafii Rzymskokatolickiej św. Zygmunta w Częstochowie [Civil Register of the Roman Catholic Parish of St. Zygmunt in Częstochowa; henceforth: ASC, PRZ]), and from 1826 in separate records kept for Jews.

${ }^{20}$ APCz, Akta Stanu Cywilnego, Okręg Bóżniczy Częstochowa [Civil Register, Częstochowa District; henceforth: ASC, OBCz], collection: Zgony [Deaths] 1829, item 53.

${ }^{21}$ In 1808, 495 Jews lived in Częstochowa. In the neighboring Nowa Częstochowa [New Częstochowa], a Jurydyka of the monastery in Jasna Góra, there were formally none. In 1826 , the two towns were merged into one. 
according to an official list from 1816, there was no rabbi in Częstochowa. ${ }^{22}$ In 1821, as a result of pressure from state authorities, the rabbi was offered an annual salary of 1,400 Polish złotys (henceforth: złp.) — quite a lot at the time. In autumn of that year, Issachar Weingott, whose name was given as Zachariasz in Polish documents, was made the first official rabbi. ${ }^{23}$ In a letter dated 16 December 1821, Weingott requested to be installed as the rabbi in Stara Częstochowa, citing the fact that he had been appointed by the kahal elders. In accordance with procedure, the Kalisz Voivodeship Commission requested information from the commissioner of the Wielun district on the "conduct" of the candidate. ${ }^{24}$ We know from the certificates submitted by Weingott that he was born in Kalisz on 1 May 1785, son of Löbel. ${ }^{25}$ For many years, he studied with the chief rabbi of Łęczyca (whose name he did not provide), Chaim Izaak Auerbach (ca. 1755-1840), who was part of the inner circle of Akiva Eger from Poznań. ${ }^{26} \mathrm{He}$ then studied for a few years in Koło with his father-in-law, Rabbi Efraim Beer Lewin, while simultaneously teaching as an assistant rabbi at the local synagogue of "divine science and world history." In Warsaw, he published a "book suitable for the Talmud," which was intended to bring recognition to local and Silesian scholars. He emphasized that he "speaks Polish, Hebrew, and German." ${ }^{27}$ Certificates backed by the synagogue supervisory body ${ }^{28}$ were accepted by the voivodeship commission, which on 18 October 1822 approved Weingott for the position of rabbi, under the condition that he comply with all national laws (especially with reference to births,

${ }^{22}$ AGAD, CWW, call no. 1429; ibid., call no. 1542, pp. 32-52.

${ }^{23}$ The name was recorded variously, e.g. Weingolt, Weingold. In Hebrew sources: "gaon Jissachar Wajngurt" (Shatzky, "Jews in Czenstochowa," 28).

${ }^{24}$ AGAD, collection: Komisja Województwa Kaliskiego [Kalisz Voivodeship Commission; henceforth: KWK], call no. 700, p. 3. The collection is no longer in operation. For this citation, I used microfilm, and for the remaining citations (call nos. 710 and 713), I used notes made available to me by Marcin Wodziński.

${ }^{25}$ Louis Lewin mentions him as the son of Szraga Fajwel (Lewin, "Ein Judentag," 297, n. 3).

${ }^{26}$ Gedalja Tiktin was also a pupil of Auerbach (BHR I/2, p. 158).

27 AGAD, KWK, call no. 700, pp. 81-84. The basis for this is a certificate issued by the synagogue supervisory body in Koło on 23 August 1822. His daughter Roza/Reyzel was born in Koło in 1812.

${ }^{28}$ In 1822, the synagogue supervisory body was listed as: Lipmann Heyman (Hayman, Haymann), Józef Hertz Kohn, and Lewek Likiernik. Earlier members were Lewek Kohn, Jakub Landau, and Judka Reycher. The names and surnames of the Jews occur variously in the sources. The version used here is that which most frequently occurs in official records and regional literature, with variations listed in brackets. 
marriages, and deaths), and that he do everything within his power to spread morality and education among the Jews. ${ }^{29}$

Weingott was also the author of the work Pithei she'arim [Open Gate], an amendment to the last passages of the Bava metsiya tractate published in Dyhernfurth (Polish: Brzeg Dolny) in 1819. He signed the title page as "Isachar ben Jehuda Lejb, from Częstochowa." ${ }^{30} \mathrm{He}$ was therefore already operating in the city at this time, further confirmation of which is his nomination. Not much is known about his work there, but he certainly did not stay long. In 1824 he became a rabbi in Płońsk, ${ }^{31}$ after signing a waiver of rabbinical rights in Częstochowa and acknowledging receipt of all money owed from the community. ${ }^{32}$

In the years that followed, the community formally managed itself without an officially approved rabbi. ${ }^{33}$ However, Jewish public registers, which were kept in Częstochowa starting from 1826, reveal the presence of an unofficial rabbi. In the register of marriages, which by law required the presence of a rabbi, "Jakub Brass" appears from the beginning as a substitute for the local rabbi (sometimes as the "rabbi's replacement"). J. Brass (sometimes Brasz, or even Braf) was not his only name-he appears additionally as Jakub Muszyn. ${ }^{34} \mathrm{He}$ also worked in Częstochowa much earlier, bearing witness as a teacher to vital records starting from $1808 .{ }^{35}$ Later documents unambiguously show that he carried out the duties of the community rabbi for local Jews.

${ }^{29}$ Ibid., call no. 700, p. 85. He was presented as a rabbi by the head of the Wielun district on 26 October 1822 (ibid., call no. 713, p. 71).

${ }^{30}$ Louis Lewin, Geschichte der Juden in Lissa (Pinne, 1904), 234; BHR I/1, p. 158, item 72.

31 AGAD, CWW, call no. 1542, pp. 53, 56, 133, 166; APCz, Akta miasta Częstochowy [Częstochowa City Records; henceforth: AmCz], call no. 448, p. 42.

32 The Polish translation of Weingott's resignation was done by Jakub Bursztyński in 1828, signed "Częstochowa 18 Adar 5584, or 19 March 1824 of the Christian era. Isachar Ben Judy Leyb from Kalisz," and attached to several other documents (AGAD, KWK, call no. 700, pp. 307-308, 312-313).

${ }^{33}$ Official lists from 1826 and 1827 do not mention him (ibid., pp. 114, 135, 162).

${ }^{34}$ In a letter from 28 April 1839, the synagogue supervisory body wrote that Jakub Muszyn performed the function of rabbi for some time before Mojżesz Majzel (APCz, AmCz, call no. 448, p. 42). He appears as Jakob Moszin Brasz in the community tax list from 1822 (AGAD, KWK, call no. 713, pp. 3-33).

${ }^{35}$ In 1809 , as a witness to the registration of the birth of the granddaughter of Abraham Majzel, he was 40 years old (APCz, ASC, PRZ, Urodziny [Births] 1808/9, p. 144, item 4). 


\section{Weingott's Re-Election as Rabbi}

The turbulence surrounding the election of the community rabbi was related to the fact that the community of Częstochowa Jews was very divided at the time, including within the synagogue supervisory body. In 1825, the Kalisz Voivodeship Commission received a complaint from Paweł Landowski, Jakub Landau, and Józef Gajfler requesting that the supervisory body be abolished, claiming that it was cheating taxes, and that instead of being elected, its members were simply submitted for approval by the former kahal. The commissioner of the Wielun district did not formally acknowledge the accusations. However, one of the accusers, namely P. Landowski, was elected as a member of a new synagogue supervisory body in 1825 (along with Lipmann Heyman and Józef Hertz Kohn). ${ }^{36}$ The divisions among the Częstochowa Jews became even more apparent during the next elections at the end of 1828. As a result, the district commissioner appealed for approval of a body consisting of the following members: L. Heyman, J. Hertz Kohn, Joachim Lerner, and Cyna Breszel. He wrote:

Although according to the law it was decided that the synagogue supervisory body should be composed of three members, it was nevertheless proposed, in accordance with the wishes of the Jews for better order and representation of individual parties, that a fourth member be added in order to eliminate ambiguities and misunderstandings between the supporters of individual candidates for this community position. ${ }^{37}$

It is not easy to clearly identify these "parties," but we do know that the Hasidim, who were very active during this period, were able to secure representation within the body in the person of Joachim Lerner. ${ }^{38}$ The remaining members represented the progressives (Józef Hertz Kohn), and most likely the traditionalists (Cyna Breszel). L. Heyman can also be counted as a progressive.

One of the factors complicating the situation in the community during this period of heated disputes regarding the makeup of the new supervisory body was pressure from the state, which continued to insist on election of a rabbi. In autumn of 1828 , Weingott returned to the city and

${ }^{36}$ AGAD, KWK, call no. 713, pp. 127-128, 131-135, 137, 183.

${ }^{37}$ Ibid., pp. 243-244.

${ }^{38}$ Together with J. Gajfler, he was among the Hasidim quarreling with the kahal about the right to use the mikvah in 1820, see Marcin Wodziński, Źródła do dziejów chasydyzmu w Królestwie Polskim 1815-1867 w zasobach polskich archiwów państwowych (Kraków-Budapest, 2011), 5, 7, 59, 60, 62, 64 . 
was elected rabbi by the majority of the community. But on 27 November 1828, Dawid Kronenberg, Izaak Feigenblatt, Szymon Guttentäger, and Lewek Kohn filed a claim against him with the Kalisz Voivodeship Commission. The same was done on 2 December by Feigenblatt, Guttentäger, and Dawid Landau on behalf of wealthy Częstochowa Jews. ${ }^{39}$ They presented Weingott as a man full of fanaticism and in opposition to the "civilization" of the Jews, who, due to the aversion of the community towards him, renounced his duties, and now wants to return with the support of like-minded individuals. They stated that the community had its own religious functionaries, and did not need a rabbi. On the other hand, Weingott's supporters demanded from the supervisory body-and later the city council-that the costs of keeping a rabbi be included in the community budget. Weingott himself appealed to the voivodeship commission for approval. ${ }^{40}$ Cyna Breszel, one of the members of the supervisory body, also appealed to the authorities in Kalisz for Weingott's approval in the name of more than 120 family heads. They were referred back to the commissioner of the Wielun district, who ordered a formal election on 9 January 1829. With the support of three-fourths of the members of the community, Weingott won again. ${ }^{41}$ This led to further complaints from his opponents to the voivodeship commission, ${ }^{42}$ and in February of that year, to the Government Commission for Religious Denominations and Public Enlightenment. The "most prominent" Jewish citizens of the city (Feigenblatt, Wolf Gerson Landau, and editor Jakub Bursztyński) reported that fifty "anti-rabbis" did not take part in the elections, i.e. the "most important and wealthy families, who contribute the most to the position;" and that the majority of "rabbinists are common and contemptible people" who do not pay taxes, ${ }^{43}$ and have no idea what competencies a rabbi in a city like Częstochowa should have. The claimants evoked government laws, recalling that, according to the plan of the School of Rabbis in Warsaw, "fanatics and obscurantists" may not be approved,

${ }^{39}$ AGAD, KWK, call no. 700, pp. 305-306, 309, 343-348. I. Feigenblatt and S. Guttentäger sent a similar letter to Kalisz on 23 December 1828 (ibid., pp. 310-314).

40 Ibid.

${ }^{41}$ Ibid., pp. 319-321, 322-323.

${ }^{42}$ In order that Weingott not be approved, "as his violent incitements have provoked hatred. However, other rightfully-thinking, wise, and important persons, with their unchallengeable arguments, have not listened to him" (ibid., pp. 315-318).

${ }_{43}$ Who are made of "the most contemptible fat, which does not pay for community burdens," and who operate on bigotry against the upper classes (AGAD, CWW, call no. 1542, pp. 55-58; AGAD, KWK, call no. 700, pp. 343-348). 
and that Weingott was a "quarrelsome and indecisive soul" (This led to his removal from service in 1824.) They also claimed that his sermons inspired fanaticism and bigotry against all civilizations of Jewish people, and that-among other things-they "fouled" candidates for the School of Rabbis. The simple fact that he desired to occupy the position of rabbi is proof of his "discreditable way of thinking," as it had caused a split in the community, and his approval would be a disgraceful example for others. They requested to postpone the term of the rabbi's employment until the School of Rabbis educated "bright shepherds, one of whom we will openly accept." 44

However, the Kalisz Voivodeship Commission also received letters in support of Weingott, including one from the "larger part of the Israeli community," signed 4 February 1829 by Józef Gajfler, one of the leading Hasidim, who is listed here as a subtenant of the kosher tax. He demonstrated that there was a lack of religious functionaries in the community, as one scholar had recently died, and that a rabbi was needed to solve problems related to the killing of livestock (e.g. to take oaths from people who had cheated the kosher tax). He also explained that "Rabbi Zachariasz Weingott, a very learned man, very virtuous, and most respectable," has moved to Płońsk after being tormented by a "few malcontents," who would not let him out of Częstochowa without signing a resignation. The community subsequently asked the rabbi to return on multiple occasions, as he had now been elected for a six-year term by nearly all its members, with the exception of a few, who, "on account of their insatiable pride and arrogance," were against him. ${ }^{45}$

The Kalisz Voivodeship Commission had previously recommended that the district commissioner investigate the accusations against Weingott. On 24 February, the commissioner submitted a report based on information from the magistrate stating that the rabbi was a model of morality and that he properly carried out his duties, but that he was also a traditionalist and continued to observe old customs. The report further explains:

The reason for the differences in opinion is the dual nature of the community, which is a result of different habits and lifestyles. The main difference between the two groups can be seen in the lives of civilized people, and in the lives of those who

\footnotetext{
${ }^{44}$ Also added here was the argument that "because of [Weingott], the community is holding secret meetings on a daily basis," which was prohibited by the Penal Code.

${ }^{45}$ Ibid., pp. 319-321. He added that two members of the supervisory body belong to the "anti-rabbi" group. One was certainly L. Kohn, and the second was likely to be L. Heyman.
} 
continue to observe old customs and traditions. The majority of traditional Jews want Weingott to follow their traditions and customs, and the other group, which consists of many people who follow newer social tendencies, demands election of someone with modern leanings. ${ }^{46}$

Before the authorities in Kalisz made their final decision, they received a letter from the Government Commission for Religious Denominations and Public Enlightenment in Warsaw recommending that they refrain from electing Weingott rabbi, as he was a fanatic in opposition to the civilization of Jews, and ordering an investigation to clear up the matter. This was a response to the letters of Weingott's opponents and-most likely - further unofficial measures they had taken with the central authorities in Warsaw. The voivodeship commission did not intend to carry out another investigation, and stated on 26 March 1829 that Weingott did not have the appropriate qualifications and that he may not be approved. It also prohibited him from carrying out rabbinical duties in the Częstochowa community, which should elect educated candidates and submit them for approval. ${ }^{47}$ Furthermore, the Government Commission took seriously the declarations of Feigenblatt and others, and asked the Committee for Jewish Affairs to indicate an appropriate candidate for the inhabitants of Częstochowa. However, the director of the School of Rabbis stated that it would produce an ample number of graduates in two years; and as a result, the election of a "qualified" rabbi was suspended. In July of 1829, Weingott requested the authorities in Kalisz to let him keep his position of rabbi in Częstochowa, indicating that he was qualified and licensed, that he had been fairly elected by three-fourths of the members of the community, and that the accusations against him had not been verified. He also pointed out that there was only a small number of malcontents plotting against him, whose only goal was to "install a member of their own families in office." The Kalisz Voivodeship Commission nevertheless decided on 21 July 1829 that it had no grounds to change the decision. Weingott then became a rabbi in Stryków, and later in Kowal. ${ }^{48}$

${ }^{46}$ Ibid., pp. 349-350, 354.

${ }^{47}$ AGAD, CWW, call no. 1542, pp. 60-61, 64-67; AGAD, KWK, call no. 700, pp. 340342,356 .

${ }^{48}$ Ibid., p. 365; AGAD, CWW, call no. 1542, p. 62. 


\section{The Third Unsuccessful Election of Weingott as Rabbi}

In 1828-1829, disputes regarding the composition of the synagogue supervisory body, as well as the position of community rabbi had people divided into two camps: rich and better-educated families; and the traditional majority. This appears to be a typical communal conflict between the "progressive" minority and the "backwards" Orthodox majority (which included the Hasidim). Arguments from the progressives better-suited the expectations of the administrative authorities, and their preferred policy of "civilizing" Jews. ${ }^{49}$ Hence the ability of the "anti-rabbis" to achieve their goal and restore the status quo. Jakub Brass still appears in vital records as "local rabbi" 50 from 22 April 1829 to 21 April 1830, when he died at the age of 64, leaving behind his wife Jette, eight daughters, and one son. ${ }^{51}$

The death of the current, albeit "unofficial," rabbi opened the next phase of conflict, as several candidates were already vying for his position by the summer of that year. One of these was Weingott, who had been elected by a majority of the community members at a general assembly, and approved by the municipal government. It was his third attempt. This was opposed by supervisory body members Lipmann Heyman, Cyna Breszel, and J. Bursztyński, who appealed to the Kalisz Voivodeship Commission for the withdrawal of his nomination. On 23 July 1830, the commission stated that the decision of the magistrate to nominate Weingott was appropriate, and that if the supervisory body continued to oppose it, they would be punished. For reasons unknown, this never happened, ${ }^{52}$ but on 26 July 1830, the supervisory body presented three candidates to the magistrate for approval: Jonas Landau (previously a rabbi in Szczerców), Mojżesz Majzel, and Natan Lerner.

Each of these candidates was significant. Natan Lerner was the brother of leading Częstochowa Hasid Joachim Lerner, who was also a member of the supervisory body at the time. Jonas Landau came from the largest local family, and initially had an advantage, as he had the support of the most prominent Jews in Częstochowa, as well as that of the supervisory body (with the exception of Lerner). He also appealed to the authorities for a nomination in August of 1830, declaring that he knew Polish,

49 Wodziński, Władze Królestwa Polskiego, 31-44.

${ }^{50}$ Until 24 July 1829; and after that, again as a substitute. It is likely that the government officials indicated to him that he was not an officially approved rabbi.

${ }^{51}$ APCz, ASC, OBCz, Zgony [Deaths] 1830, item 15.

52 Related correspondence, AGAD, KWK, call no. 710. 
and that he would not burden the community's coffers. ${ }^{53}$ However, in October, the Government Commission for Religious Denominations and Public Enlightenment received two complaints: one from several of his opponents, ${ }^{54}$ and another signed by Lobel Berman and Jakub Frayman "in the name of the Jewish people in the community." The complaining parties tried to discredit Landau by arguing that he was constantly busy in his tin spoon factory, and that he was a loan shark related to two-thirds of the Częstochowa inhabitants. They demanded that his election be annulled "due to bad conduct and lack of qualification." The government authorities ordered an investigation into whether his election took place in accordance with the regulations, and whether he possessed the appropriate qualifications. ${ }^{55}$ The investigation was commissioned to the magistrate of Częstochowa by the voivodeship commission, but it was never carried out due to the subsequent outbreak of the November Uprising of Poles against the Russian Empire. The case remained suspended, and the community continued to function without a rabbi approved by the state authorities, although we know that these obligations were de facto performed by Mojżesz Majzel (see below).

Despite the above, the voivodeship administration was constantly pushing for an election on the logic that a city as big as Częstochowa must have a rabbi with formal competencies and a "decent salary," especially since the Administrative Council passed a resolution on 6 June 1830 that divided the country into religious districts (de facto religious communities) with officially approved rabbis. ${ }^{56}$ Correspondence related to this issue was sent to Częstochowa in 1831, 1832, and in Spring of 1833. The synagogue supervisory body replied on 26 May 1833 that it could not elect a rabbi due to financial problems; and aside from that, it had a qualified "rabbi" who was working for free. Still, the head of the Wielun district recommended election of a rabbi under supervision from the municipal authorities within eight days. The persistence of the government officials was matched by the stubbornness of the supervisory body, which called a community meeting

53 The municipal government supported his statement in a letter to the authorities of Kalisz from 31 August 1830.

${ }^{54}$ Moszko Weitzen, Markus Gold, L. Bermann, and Icyk Frayman (AGAD, KWK, call no. 710$)$.

${ }_{55}$ AGAD, CWW, call no. 1542, pp. 68-69.

${ }^{56}$ Only such a rabbi or his temporary substitute could perform religious rites on community territory (Dziennik Praw Królestwa Polskiego, vol. 13, 1830, pp. 147-160; Kirszrot, Prawa Żydów, 27-42). 
solely for the purpose of passing a resolution on the impossibility of an election. After receiving another letter from the authorities threatening to enforce the order,${ }^{57}$ the supervisory body appealed to the central authorities in Warsaw. In a letter from 14 July 1833, it stated finances as an argument against the election (as the salary of a rabbi would be 3,000 złp.), as well as the fact that the community already had someone with rabbinical competencies who was carrying out all religious obligations free-of-charge. Indeed, it couldn't hold an election "even if the rabbi agreed to accept a small salary," and the already-active rival was supported by adherents from many families. The ongoing discussion between the groups led to nothing, and election of another rabbi was impossible due to costs. Moreover, the rabbi would be exposed to the hostility of "local theologians." The supervisory body therefore asked the Government Commission to discern whether it would be good to "force" the community to elect a rabbi. ${ }^{58}$

The Jewish community in Częstochowa had actually been suffering from a considerable budget deficit since the November Uprising, ${ }^{59}$ so intervention turned out to be effective. ${ }^{60}$ In a decision from 6 December 1833, the central authorities referred to a resolution of the Administrative Council from 7 September 1830 stating that substitutes may perform "rites" in communities without rabbis, that vital records must be filed by government officials, and that forcing supervisory bodies to elect a rabbi would only generate constant complaints. Therefore, all the community had to do was propose a candidate or substitute with the appropriate moral qualities and qualifications who would carry out his duties for free. ${ }^{61}$ This decision was thus in favor of the supervisory body, and the local authorities ceased their attempts to reinforce binding regulations for the time being. ${ }^{62}$

57 AGAD, CWW, call no. 1542, pp. 70, 71, 74-75, 76; AGAD, KWK, call no. 710.

${ }^{58}$ AGAD, CWW, call no. 1542, pp. 70-73. In 1833, the supervisory body consisted of: L. Heyman, C. Breszel, and Joachim Lerner.

${ }_{59}$ During which Julian Masłowski, leader of the noble levy (pospolite ruszenie) of the Wielun district, took some 15,000 złp. from the community coffers in Częstochowa, Kłobuck, and Krzepice; see Janusz Spyra, "Pieniądze Masłowskiego: Przyczynek do kwestii żydowskiej w powstaniu styczniowym," in Maciej Trąbski, Norbert Morawiec, Robert W. Szwed (eds.), Powstanie styczniowe $w$ regionie częstochowskim $i w$ województwie kaliskim (1863-1864) (Częstochowa, 2014), 113-122.

${ }^{60}$ Although the Kalisz Voivodeship Commission stated on 24 October 1833 that the community consisted of over 1,500 members, it was one of the richest, and amount of the salary depended on the supervisory body.

${ }_{61}$ AGAD, CWW, call no. 1542, pp. 80, 82-85; AGAD, KWK, call no. 714.

${ }^{62}$ In any case, records show no correspondence concerning the rabbi until 1839, which suggests that the community did not even submit the substitute rabbi for approval. 
However, we know from financial documents of the Jewish community in Czesstochowa that the duties of the community rabbi were carried out by Mojżesz Majzel—one of the three candidates submitted by the supervisory body in July of 1830 . He is listed in Jewish encyclopedias, but his relations with Częstochowa were unknown up until then. Mojżesz Majzel (Mayzel, Maisel, Meisel, etc.), also called Kurnik (or Kornik, Kronik, Korniker, etc.), was born in Częstochowa around 1770. He appears in vital records as a witness in 1811; and his son, Jakub, was born in $1812 .{ }^{63}$ At that time, he worked as a teacher and dayan. He later worked in Prussia as Mose ben Akiba Kornik. He was also a rabbi in Flatow (Polish: Złotów) in Western Prussia, as well as in Glogau (Polish: Głogów) in Lower Silesia. On the occasion of the liberation of the city from the French army in April 1814, he wrote an expression of gratitude in Hebrew entitled Tefilah ve-toda. The German translation was published that same year in Breslau (Polish: Wrocław). His most important work is the homiletic Jemin Mosze (Breslau, 1824). After the death of Abraham Tiktin, he wrote Evel yahad, a eulogy which was also published in $1824 .{ }^{64}$ Additionally, he was the author of Davar be-ito, published in Breslau in $1817 ;^{65}$ and a commentary on the Book of Esther entitled Teshu'at hen, published in 1821 in Dyhernfurth. He became a rabbi there around $1823 .{ }^{66}$ In 1830 or soon after, he returned to Częstochowa, ${ }^{67}$ and is listed in the budget records of the community there as a substitute rabbi, or "chief clergyman." He was paid a regular, albeit small, salary. In 1837, it was indicated that the salary was in line with the "will of the entire community." ${ }^{68} \mathrm{He}$ was therefore the de facto

${ }^{63}$ APCz, ASC, PRZ, Urodziny [Births] 1812, item 24, p. 166. His wife was Hinda, daughter of Wolf Kalonymos. Short biogram in the BHR I/2, p. 653, item 1227. For some time, he lived in his father-in-law's home in Żarki.

${ }^{64}$ Cf. Franz D. Lucas, Margret Heitmann, Stadt des Glaubens: Geschichte und Kultur der Juden in Glogau (Hildesheim-Zürich, 1991), 245; BHR I/2, p. 551, item 984.

${ }_{65}$ This is a critical evaluation of Bendavid's work, see Lazarus Bendavid, Zur Berechnung und Geschichte des jüdischen Kalenders (Berlin, 1817). Cf. W. D. Block, "Urtheil über das Lazarus Bendavid'sche Werk über den jüdischen Kalender," Allgemeines Archiv des Judenthums 2 (1842), 289.

${ }^{66}$ BHR I/2, p. 653, item 1227; Bernhard Brilling, Die jüdischen Gemeinden Mittelschlesiens: Entstehung und Geschichte (Stuttgart, 1972), 67-68. His successor was active starting from 1832.

${ }^{67}$ In 1832, he was a witness to the last will and testament of Lewek Berman, see Dariusz Złotkowski, "Wiedząc dobrze to z wyroków Boga Najwyższego, iż kto się rodzi, umierać musi...": Testamenty $z$ pierwszej połowy XIX wieku w świetle akt notariuszy częstochowskich, [henceforth: Testamenty], part 2 (Częstochowa, 2006), 252, 297-298.

${ }^{68} \mathrm{APCz}, \mathrm{AmCz}$, call no. 454, pp. 81, 183; ibid., call nos. 453, 454, 455, 459, 460. He also volunteered as an emissary (Testamenty, part 2, pp. 286-287). 
community rabbi, and remained so until he died on 13 March $1839,{ }^{69}$ leaving behind his wife Hinda Kalman, and seven children, including his son Jakub. Subsequent writings from the end of 1839 emphasized that he was satisfied with a salary of $250 \mathrm{złp}$., and that he was strongly committed to spreading knowledge and light among his fellow believers. ${ }^{70}$

\section{Zachariasz Weingott: Again Rabbi in Częstochowa}

One month later, in April of 1839, Zachariasz Weingott was again elected rabbi in Częstochowa. Upon announcing this, the members of the synagogue supervisory body (C. Breszel, Lewek Kohn, and Icek Seidemann) argued that because there was now no one else fit to perform religious duties - which of course was untrue-the community had authorized the supervisory body to bring back the popular rabbi. Weingott was brought in from Kowal on 28 April 1839 on five two-horse carriages. ${ }^{71} \mathrm{He}$ was supposed to receive a salary of $1,800 \mathrm{złp}$., in addition to fees charged for marriages "according to the current custom in the entire Jewish world."

This time too, it did not happen without protest. Almost immediately, Salomon Bendawid approached the Kalisz Voivodeship Commission with a request for the installment of a qualified rabbi for Częstochowa. The argument was that the previous rabbi, Mojżesz Majzel, had died, and that the "class of zealots, who are the worst enemies of humanity and science, demoralizing themselves and the public coffers of the people that obey them," were trying to force their candidate through, which would unfailingly contribute to the inhibition of "a civilization that is beginning to prosper." The municipal government itself did not raise any objections against Weingott, and stated that there was no one living in Częstochowa under the name "Bendawid." In November, the authorities in Kalisz received another letter addressed to the Government Commission for Religious Denominations and Public Enlightenment, whose author signed first as "N... L...au," but added that in order to avoid repression, he would further sign as Salomon Ben Dawid. This was clearly someone from the

${ }^{69}$ He died on 13 March 1839 (APCz, ASC, OBCz, 1839, item 19). His tombstone still exists, but with 15 February as his date of death, see Wiesław Paszkowski, Cmentarz żydowski w Częstochowie. Przewodnik (Częstochowa, 2012), 1: 156.

${ }^{70}$ Archwum Państwowe w Łodzi [State Archives in Łódź; henceforth: APŁ], collection: Rząd Gubernialny Piotrkowski [Provincial Government in Piotrków; henceforth: RGP], call no. 2504, f. 131. He is listed as rabbi in the marriage acts of his daughters.

${ }^{71} \mathrm{APCz}, \mathrm{AmCz}$, call no. 448, pp. 42-43; ibid., call no. 456, p. 86. 
Landau family (probably Nehemiasz). ${ }^{72}$ The letter contained a complaint that the community had thus far had an unofficial rabbi for a small amount of money, ${ }^{73}$ and that now the supervisory body was funding the expensive luxury of an official one. The complaint was made solely on account of the ongoing rivalry between two influential families, for "without prior consultation with the town as a whole, one family installed Zachariasz Weingott as rabbi to spite the other." In the end, Weingott was removed from the city at the close of 1828 "due to his inability." "I4 In a second letter, dated 19 December 1839 in Częstochowa, Icyk Frafermauer, on behalf of the middle and lower classes, requested that an official rabbi not be approved, citing the same arguments: $;{ }^{75}$ namely, that "because of the hatred between two families, who are constantly at odds with each other," one of them, without the knowledge of the middle- and lower-class taxpayers of the community, forced the election of a rabbi with such a high salary. In response to these accusations, the supervisory body emphasized that it had to employ a rabbi due to pressure from the authorities, and that it had to offer Weingott a higher salary. Indeed, not only did he now have five children, but a larger "parish" to look after, as the community had doubled in size since 1822-1824. In another letter, the supervisory body added that nearly everyone had voted for him at the community meeting. ${ }^{76}$

Initially, the state authorities were again disinclined to approve Weingott-despite the fact that he had been officially elected under the supervision of the magistrate at the beginning of 1840 - as he still did not meet the conditions outlined in the plan of the School of Rabbis. In a few letters, the supervisory body attempted to convince the central authorities to change their mind, arguing that the entire community wanted Weingott as rabbi, ${ }^{77}$ and that it needed him to manage the kosher income and ritual slaughter. ${ }^{78}$

${ }^{72}$ More information below. AGAD, CWW, call no. 1542, p. 113; AGAD, KWK, call no. 710 .

${ }^{73}$ One of the most capable rabbis, M. Majzel, diligently studied science and spread light among his fellow believers for $250 \mathrm{złp}$. After his death, Jakub Eliasz Rozen carried out these duties for free.

74 APL, RGP, call no. 2504, f. 131. Determination of which families exactly will be attempted in the next sections of the article.

75 Ibid., ff. 150-152. It is also mentioned in another place (f. 122v) that a member of the "clergy" had been serving in this capacity, and that now an official rabbi had been elected.

${ }^{76}$ AGAD, CWW, call no. 1542, pp. 115, 129-132, 133.

${ }^{77}$ In a letter from 14 January 1840 , it stated that even if it found a rabbi who met the requirements, the community would not accept him.

${ }^{78}$ Ibid., pp. 115, 129-132, 134. In 1841, it also signed a statement that Weingott was the ideal rabbi, and that he had been fulfilling his duties since 1 March 1839. 
The body was also supported by the voivodeship authorities; and the central authorities had already abandoned their policy of integration towards Jews, as they were now more concerned with maintaining peace in Jewish communities and ensuring proper collection of taxes. Weingott was finally accepted, but among other things, he had to submit his previous rabbinical permits and certificate of clean criminal records. ${ }^{79}$ Also, due to an 1836 ban on Jews living within three miles of the border, Weingott had to obtain a separate permit for residence in the border area, which he was granted by the Administrative Council on 6 June $1841 .{ }^{80}$ It was not until two years later that Weingott received full, official rabbinical rights. During the interim period, the supervisory body could not pay his salary, so he was forced to fall into debt. ${ }^{81} \mathrm{He}$ finally received his due payments when, on 30 July 1841, he swore an oath of allegiance to the government, and declared that he would support the "views of the government intended to morally educate the Israelites." $\$ 2$

We do not know much about the activity of Zachariasz Weingott as rabbi in Częstochowa. We do know that he headed a council whose task was to establish a three-class school for Jews that would also teach "lay" subjects. We also know that, from December 1841 to 1848 , he had to work with the supervisory body as composed of Eicyk Ginsberg, Gerson Mojżesz Landau, and Icek Winer. ${ }^{83}$ For the rabbi, this meant problems with regular pay. ${ }^{84}$ An 1846 letter from his son, Michał Beer Weingott, indicates that the supervisory body was not paying his father's salary on purpose-which was not necessarily true-and that his father was seriously ill, which was why he was staying with his son in Kalisz. ${ }^{85}$ Zachariasz Weingott had other children with his wife Marianna Lewin (including a few daughters), and died in Breslau on 22 August 1852. ${ }^{86}$

${ }^{79}$ Ibid., pp. 139, 145, 166.

${ }^{80}$ Ibid., pp. 113-128, 139, 146, 160-161, 162; APŁ, RGP, call no. 2504, ff. 162-164, 168, 338, 400, 441; AGAD, KWK, call no. 710.

${ }^{81}$ APŁ, RGP, call no. 2504, f. 338; AGAD, CWW, call no. 1542, pp.142, 144, 163-164.

82 APCz, AmCz, call no. 456, pp. 89-93.

${ }^{83}$ APŁ, RGP, call no. 2504, f. 915; AGAD, CWW, call no. 1542, p. 208.

${ }^{84}$ APŁ, RGP, call no. 2504, ff. 607, 783, 877, 894, 934. This problem was solved thanks to a letter written on 17 August 1846 (ibid., f. 938). Cf. AGAD, CWW, call no. 1560. The communities that had employed him previously also failed to pay his salary on time (ibid., call nos. 1665, 1722).

${ }^{85}$ APCz, AmCz, call no. 448, pp. 419-421. Michał Beer Weingott served as rabbi in Piotrków Kujawski (AGAD, CWW, call no. 1745).

${ }^{86}$ See Lewin, "Ein Judentag," 297, n. 3; APŁ, RGP, call no. 2505, f. 708. 


\section{Official Sources and Their Research Value for the History of Jewish Communities}

Official sources describe in fair detail the long-standing dispute over the position of the community rabbi in Częstochowa, wherein the main character was Zachariasz Weingott, a rabbi who was elected and "disapproved" on several occasions. They paint a reasonably credible picture of the facts, which should nevertheless be critically analyzed. The multitude of letters sent to the administrative authorities make it impossible to separate the whole truth from obvious misrepresentation. However, we can find examples of "intentional truth," i.e. information that persuaded the authorities to make decisions favorable to a given party. The authorities were obliged by law to respond to complaints and requests, yet they had neither the intention nor the competency to become entangled in the affairs of their Jewish subjects. The most common strategy was thus to keep issuing letters or resolutions stating their intention to "settle" the matter, i.e. to send it $a d$ acta ${ }^{87}$ The petitioners did not want to reveal any more than was necessary. Indeed, the willingness displayed by the "enlightened" community members to employ a graduate of the School of Rabbis, someone with a totally secular education, is just as nonsensical as Weingott being described as a fanatic and obscurantist. Criticizing his behavior and credentials was a convenient way of discrediting him in the eyes of the state authorities, who already had a negative view of rabbis. In 1839, Weingott became the "most beloved" candidate in the communityso much so that even educated persons stopped contesting his position.

A deeper analysis of official sources indicates that the parties had various motives for engaging in the dispute, which doubtlessly affected many aspects of community life. One was reluctance on the part of the synagogue supervisory body and the majority of the community members to employ an official rabbi, which would have been costly for everyone. This was made clear after Weingott's death, when one of the local "clergymen," Jakub Eliasz Rozen, took over his duties as a provisional assistant rabbi. This temporary "volunteer" arrangement became permanent when the position was approved for the years 1853-1858. The salary of the rabbi was omitted, and his duties were imposed on "clergymen of the Jewish faith acknowledged by the deceased and who are trusted by the community."

${ }^{87}$ See also Alicja Kulecka, Wapno i alabaster: Biurokratyczna wizja rzeczywistości w raportach urzędowych Królestwa Polskiego (1815-1867) (Warsaw, 2005). 
These "clergymen" were Natan Oderberg, Szlomo Sztencel, Joachim Landau, and Jakub Rozen. ${ }^{88}$ They would perform these duties in return for voluntary fees. The supervisory body upheld this arrangement until 1859, when the Jews of Częstochowa decided to elect another rabbi under the threat of community dissolution. Once again, the richer families in the community pitted their candidate, Menachem-Mendel Löwenstein (Löwenstamm) from Poznań, against Szmul Goldsztajn, who was supported by the traditionalist majority. Due to the lack of consensus, the elections were cancelled. At the end of 1859, Izaak Rabinowicz was elected rabbi; but after his unexpected death in 1868, the position was left empty until 1888. ${ }^{89}$ Therefore, the Jewish community in Częstochowa, which had existed since the beginning of the 1800s, did not have an official rabbi for the majority of the century, and yet its religious needs were still met..$^{90}$

The election and approval of a rabbi who would suit the "needs of the day" was sought by the voivodeship, district, and municipal authorities mainly for the purpose of enforcing regulations. The central authorities, with their declared commitment to reforming Jews, took a wavering stance on the issue, as they were unable to discern the true nature of the situation, and gave in to non-substantive pressures. In the end, they were most concerned with maintaining peace and proper collection of taxes within the community. ${ }^{91}$

Thanks to the "cheap" labor of rabbis such as Jakub Brass and Mojżesz Majzel, who were modestly rewarded in a manner typical of traditional Judaism, the local community was able to manage with all ritual requirements while saving on expenses. Had these rabbis been official, the community would have had to pay an official salary, which would have been subject to control from the administrative authorities. ${ }^{92}$ At a certain point, the supervisory body stopped hiding that an unofficial rabbi was active in Częstochowa. In fact, in the Kingdom of Poland, ${ }^{93}$ as well as in the

${ }^{88}$ The latter, perhaps due to seniority, had a distinguished position (APŁ, RGP, call no. 2505, ff. 260, 661, 666, 682, 787).

${ }^{89}$ For more information, see Spyra, “Żydowski ksiądz?," 144-149.

90 This was no exception (see Stampfer, Families, 285-288).

${ }_{91}$ Wodziński, Wtadze Królestwa Polskiego, 133, 141, 145.

92 Although not consistent in this respect, official regulations granted rabbis rights that were equal to those of supervisory bodies (Kirszrot, Prawa Żydów, 44, 48).

${ }_{93}$ Cf. Robert Kuwałek, "Urzędowi rabini lubelskiego Okręgu Bóżniczego 1821-1939," in Tadeusz Radzik (ed.), Żydzi w Lublinie: Materiaty do dziejów społeczności żydowskiej Lublina (Lublin, 1995), 1: 28-31. Many other rabbis worked under the wing of the official rabbi. 
modernized Jewish communities of Western and Central Europe, it was common to avoid employment of an official community rabbi. In Western and Central Europe, this was a result of the desire to reduce community expenses; whereas in the Kingdom of Poland, it was a result of the desire to avoid the authorities, as well as the inability to reach a consensus as to who the community rabbi should be. The correspondence analyzed also confirms a large discrepancy between the factual state of affairs, and that declared to administrative institutions, which is generally the case in situations when oppressive government orders clash with defensive responses from groups that are discriminated against. ${ }^{94}$

\section{The Community Rabbinate and Rival Groups}

Whether due to pressure from the authorities or other circumstances, periodic attempts were made in Częstochowa to elect an official rabbi at meetings of community members. Every time, Zachariasz Weingott emerged at the winner (in 1828/29, 1830, and 1839/40). This was most often resisted by "enlightened" community members, i.e. representatives of wealthier families, who generally constituted the majority of lay leaders. Yet despite the opposition of supervisory body members to the majority of the community, all were able to unite in the face of demands from the administrative authorities.

However, it is clear from the course of events that the Jewish community in Częstochowa was divided into rival camps: the progressives, ${ }^{95}$ the traditionalists, ${ }^{96}$ and the Hasidim. This corresponds to what we find in the literature; namely, that the Jewish community in the Kingdom of Poland in the nineteenth century was divided into supporters and opponents of a modernized approach to religion. Częstochowa was a part of the Prussian state for a dozen or so years, and after 1815 was close to the Prussian border. The local Jews spoke German, and due to their economic and family connections, they were well-adapted to the changes that were taking place in Prussia and Western Europe. As early as 1818, a group

${ }^{94}$ Cf. Janusz Spyra, Żydzi na Ślasku Austriackim 1742-1918: Od tolerowanych Żydów do żydowskiej gminy wyznaniowej (Katowice, 2005), 53-54, 125-128.

${ }_{95}$ We cannot absolutize the belonging of Jakub Bursztyński, seen a supporter of reform, to this first group. In most cases, he appears in the above-mentioned letters as community secretary, obliged to express the views of the synagogue supervisory body.

${ }^{96}$ A letter from the commissioner of the Wielun district dated 24 February 1829 confirms these religious divisions. 
of Częstochowa Jews proposed establishment of a school based on the western model. Many of these Jews subscribed to Haskalah writings, including those above-listed as opponents of Weingott. ${ }^{97}$ Some time later, Jakub Bursztyński presented in the German-Jewish press an image of one of the most modern communities in the Kingdom of Poland, which had contacts in Silesia, and was combating the Hasidic "plague." Writings from the end of 1828, the beginning of 1829 , and 1830 suggest that most wealthy families tended towards "progressive" Judaism and employment of a "modern" rabbi. This is in line with the stereotype that better-educated Jews were in favor of modernized Judaism, and that poorer classes held on to a more traditional understanding of religion and Jewish customs. ${ }^{99}$ Wealthier Częstochowa Jews were undoubtedly well-adapted to the social changes taking place. Indeed, they were able to take advantage of the stereotypes that dominated administrative culture, as well as the expectations of the authorities with regard to the modernization of Polish Jews. But the tendency of wealthier Jews to favor a modern lifestyle did not necessarily mean full identification with and implementation of the model of Judaism initiated by Moses Mendelssohn (and especially his more radical supporters). Everything depended on individuals and local circumstances.

Marcin Wodziński first wrote about the Hasidim in Częstochowa in the context of an 1820 dispute over their use of the community mikvah. They had been active in the city since around 1810, and since 1815 had been running their own shtiebel. ${ }^{100}$ In other works, Wodziński conservatively estimates the number of Hasidim in the city at the time to be around 3-5 percent, and possibly up to 7 percent of the Jewish population. ${ }^{101}$ This appears to be an underestimation, as they may have actually accounted for

${ }^{97}$ Among others: Eicyk Ginsberg, Gerson Landau, Dawid Landau, and I. Fajgenblatt (Shatzky, "Jews in Czenstochowa," 14, 18-19, 30-31). On the graves of Majer and Eicyk Ginsberg are German inscriptions written in Schwabacher, see Wiesław Paszkowski, "Na częstochowskim cmentarzu żydowskim: Szkice genealogiczne i historyczne," in Jerzy Mizgalski, Małgorzata Soja (eds.), Tożsamość a stereotypy: Żydzi i Polacy (Częstochowa, 2014), 286.

98 J. B.[ursztyński], "Russland und Polen: Czenstochau," Allgemeine Zeitung des Judenthums 5 (1841), 40: 567-568.

${ }^{99}$ In the understanding of Yakov Shatzky, who observed supporters of modern Enlightenment ideals in the above-mentioned families.

${ }^{100}$ Marcin Wodziński, "Chasydzi w Częstochowie: Źródła do dziejów chasydyzmu w centralnej Polsce,” Studia Judaica 8 (2005), 1/2: 279-301.

${ }^{101}$ Marcin Wodziński, Oświecenie żydowskie w Królestwie Polskim wobec chasydyzmu: Dzieje pewnej idei (Warsaw, 2003), 110, n. 78, 80; id., "How Many Hasidim Were There in Congress Poland? On the Demographics of the Hasidic Movement in Poland during the First Half of the Nineteenth Century," Gal-Ed 19 (2004), 28-30; id., "The Socio-Economic 
up to 10 percent. However, these figures did not reflect their influence. They were highly motivated, and their aspirations were supported by many wealthy sympathizers. ${ }^{102}$ According to the testimony of J. Bursztyński, the Częstochowa Hasidim were supporters of a tzaddik from Radoszyce, Isachar Ber (1765-1843). Also, in the nearby village of Lelów, lived a famous Lelower named Dawid Biderman who was closely connected with the Horowicz and Gotlieb Jewish families from Częstochowa. ${ }^{103}$ In 1820, the Hasidim comprised a group of a dozen or so families, whose competition consisted of over a hundred families. They were most often represented by Berek Kohin (Kohn) ${ }^{104}$ Józef Gajfler, and Joachim Lerner; but there were others as well, including Natan Gotlieb and Berek Gothilf. The latter is likely to be the same person as Berek Gottlieb, who in 1816 was one of four kahal members in Częstochowa. ${ }^{105}$ At that time, the Hasidim were already playing a significant role in the life of Częstochowa Jews, and many were wealthy. ${ }^{106}$ Józef Gajfler (Gaifler, Gayfler), born around 1781, was an innkeeper, who in 1811 became an alcohol producer and retailer. In 1822, the community owed him money borrowed for the needs of the synagogue. ${ }^{107}$ Then he was a subtenant of the kosher tax, and on behalf of the "greater part of the Israeli community," pushed for the approval of Weingott as community rabbi. Joachim Lerner (b. ca. 1783) was a canvas producer. Up until the 1840s, when a competitive center in Łódź started to develop, this was a very profitable business in Częstochowa. He enjoyed the trust of the administrative authorities, and in 1830 received a loan of 5,500 złp. from a government fund for the purchase of a home

Profile of a Religious Movement: The Case of Hasidism," European History Quarterly 46 (2016), 4: 668-701.

${ }^{102}$ Ignacy Schiper, Przyczynki do dziejów chasydyzmu w Polsce, ed. Zbigniew Targielski (Warsaw, 1992), 65-72.

${ }^{103}$ Paszkowski, "Na częstochowskim cmentarzu żydowskim," 293-295. One of the community taxpayers in 1822 (AGAD, KWK, call no. 713, pp. 3-33) was Awigdor Bidermanpossibly one of the Lelower's sons.

${ }^{104}$ Unfortunately, it was not possible to more precisely identify Berek Kohin, as there were at least three people using the name Berek Kohn in Częstochowa at that time. This may refer to Berek Bermach, who is listed as "Berek Kohn Bermach" in the 1822 tax list.

105 AGAD, CWW, call no. 1429.

106 The 1822 tax list shows three Hasidim (known from 1820) to be among the 22 most significant taxpayers: Lerner, Gajfler, and Zelig Markowicz. A fourth was likely to be Mendel Horowicz, one of whose daughters married Joachim Lerner, and the second Abraham Lerner, his brother.

107 Ibid., call no. 1542, p. 45; Dariusz Złotkowski, "Spór o dochody z propinacji w Starej Częstochowie w ostatnich latach Księstwa Warszawskiego,” Studia Historyczne 41 (1998), 520,524 . 
in Częstochowa (as did other Jews ${ }^{108}$ ). He had become a member of the supervisory body one year earlier. Of course, this does not mean that he represented an entire third or fourth of the community, as the number of body members was limited, ${ }^{109}$ but it does indicate that the Hasidim were not just an insignificant and ruthlessly oppressed minority.

Most community members stood somewhere in between the progressive families and the Hasidim. In the first half of the nineteenth century, the community in Częstochowa grew rapidly-from 495 members in 1808 to 2,976 in 1857, which constituted about 34.5 percent of the city's inhabitants. These newcomers primarily came from neighboring towns and villages, and were traditionally religious. All the relevant sources indicate that most families voted for Weingott, thus his broadest "social base" consisted of these lower- and middle-class Jews.

These general findings only explain the history and nature of the dispute to a small extent. For a better understanding, we must consider the "human factor," i.e. the various and often conflicting interests of the community's social groups, as well as the most influential persons and families. As early as July of 1829, a letter from Zachariasz Weingott suggests that his opponents wanted simply to choose a rabbi from among their own family members. This is confirmed in a letter from 14 July 1833, as well as in other documents that testify to the rivalry between the two families, each supporting their own candidate. Archival materials (including vital records kept during the Duchy of Warsaw ${ }^{110}$ ) and notarial documents made available by Dariusz Złotkowski allow us to attempt to determine which families. Needless to say, they are likely to be among the richest families which contributed significantly to the rise of the Jewish community in Częstochowa at the end of the eighteenth century and the beginning of the nineteenth century. An 1861 report in Jutrzenka, published on the basis of community documents and recollections of elder community members, counts Abraham Majzel, Abraham Ginsberg, Nachman Berman, Wolf and Ch.[aim] Mojżesz Landau, and Lewek and Marek Kohn among its

${ }^{108}$ Lewek Kohn received 10,000, Józef Zand-5,000, Cyna Breszel-13,000; see Ryszard Kołodziejczyk (ed.), Częstochowa. Dzieje miasta i klasztoru jasnogórskiego, vol. 2: W okresie niewoli 1793-1918 (Częstochowa, 2005), 254; Testamenty, part 2, p. 115.

${ }^{109}$ In 1830, the number of members that could be elected to the supervisory body was reduced to four higher-class taxpayers (Kirszrot, Prawa Żydów, 47).

${ }^{110}$ See above, footnotes 19 and 20. The biographical information provided below is taken from both series of record books. For lack of space, I have omitted source references and less important family relationships. 
founding members. Although they were "old-fashioned" individuals, it was thanks to them that the modern community came to fruition. ${ }^{111}$ Other documents also confirm this. ${ }^{112}$ Nevertheless, it is worth mentioning that they did not act alone.

\section{"Family Politics" in the Jewish Community}

We can assume that the de facto rabbi in 1833, with whom the supervisory body cooperated yet could not employ due to the expected opposition, was Mojżesz Majzel. ${ }^{113}$ His social background is easy to determine, as he came from one of the oldest and richest Jewish families in Częstochowa. His father was Abraham, son of Mojżesz, a tavern keeper and one of the first Jews who were able to buy a home in the city under Prussian rule. He died in 1823 at the age of 92. Rabbi Mojżesz had two brothers, alcohol producer and retailer Anzel and merchant-landlord Majer (who also went by the name Kurnik), and a sister, Braydla, wife of Berek Berman Ginsberg. Anna, the daughter of Majer Majzel, was married to Eicyk Ginsberg. The Majzels were closely tied to the Ginsbergs, whose oldest representative was a man named Abraham who was active at the end of the eighteenth century and the beginning of the nineteenth century. We do not know much about him. Better known is Berek [Berman] Ginsberg (ca. 1771-1827), probably Abraham's son, and one of the richest Częstochowa Jews-something we know from his last will and testament, in which he estimated the worth of his assets at 19,000 złp. He left behind five sons, including Majer and Eicyk; and chose his brother-in-law Mojżesz Majzel (referred to as Kurnik) — who at the time was in Dyhernfurth in Silesia-to be their caretakers (with the exception of his oldest son, Majer, and his son-in-law, Icyk Frayman). ${ }^{114} \mathrm{He}$ also appointed Jakub Moszyn (i.e. Rabbi Brass), Józef Kohn, Mojżesz Tobiasz, Berek Barmach, and Joachim Lerner to the Family Council, which was tasked with managing the family estate. ${ }^{115}$

111 "Zawiązanie się i wzrost gminy izraelskiej miasta Częstochowy,” Jutrzenka 1 (1861), 7: 52-53.

${ }^{112}$ For example, in 1798 the leaders of Częstochowa Jews were Joachim Berkowicz Berman, Wolf Landau, and Abraham Meisel. The same was the case in 1808. In 1797, Joachim Berkowicz (in Jutrzenka under the name of Nachman Berman) was the first Jew to obtain town privileges in Częstochowa.

${ }^{113}$ Without a doubt, it was him who Z. Weingott was writing about in his 1829 letter.

114 Testamenty, part 2, pp. 113-115.

115 APCz, Notariusz [Notary] Ignacy Budrewicz, call no. 5, item 4. In Złotkowski's edition (Testamenty, part 2, p. 115), he is erroneously listed as "Serner." 
Mojżesz Majzel was a prominent Talmudic authority associated with the Silesian Tiktin family, so it would be difficult to classify him as a "reformer," although he could be considered as such in comparison with other Orthodox rabbis from Central Poland. His relations with the Tiktins were no accident. As aforementioned, Gedalja Tiktin was born in Czestochowa in 1808, and his father Salomon was closely tied to the city. In 1810, Salomon married Ruchla, daughter of Wolf Landau. Two years later, as a merchant residing in Częstochowa, ${ }^{116}$ he registered the birth of his son, Wolf. This may have only been a declaration made to the authorities. However, in accordance with Jewish tradition, it is certain that after Salomon was married, he stayed at his father-in-law's home for some time. ${ }^{117}$ The progressive families thus pushed for a rabbi with conservative religious beliefs. The presence of Joachim Lerner in the Ginsberg Family Council demonstrates that the division within the community of Częstochowa Jews was more complicated than simply being between supporters of modernization, the traditional majority, and the Hasidim. Jakub Brass (Muszyn) was probably a traditional Talmudist, although he does not appear to have been closely related to Częstochowa's richest families. ${ }^{118}$

It is more difficult to determine who supported their competitors, especially since there were at least a few people with rabbinical qualifications acting in Częstochowa in the 1830s and 1840s. One of these was mentioned starting from 1832, namely, Jakub Eliasz Rosen (sometimes referred to as a teacher), who performed his duties for free after Majzel's death. Juda Berkowicz and Salomon Sztencel also appear as "clergymen." Particularly noticeable is Jonas Landau, who combined his religious duties with other economic undertakings. As mentioned above, he had previously been a rabbi outside of Częstochowa, ${ }^{119}$ and was the owner of a spoon factory. He was also a money lender, and in 1841-1842 was a tenant of the

116 APCz, ASC, PRZ, Śluby [Marriages] 1809/10, item 6, p. 95 (here as Salomon Dyktyn, son of Aron, a rabbi from Glogau); ibid., Urodziny [Births] 1812, item 26, p. 178 (S. Dykten).

${ }_{117}$ Later, in 1847, Hertz Kohn married the daughter of Salomon Tiktin and Rosa Landau.

${ }^{118}$ His children were mainly daughters who married either people from outside of Częstochowa or craftsmen (we do not know the fate of his older daughters). There are many people with the name Muszyn or Musin that appear as craftsmen or merchants in vital records.

119 In Szczerców, as recorded in AGAD, KWK, call no. 710. But in birth records from 1828 (APCz, ASC, OBCz, Urodziny [Births] 1828, item 69), he is mentioned as a rabbi in Szczekociny, and a merchant in Częstochowa. 
synagogue scroll tax. In 1836, he again requested to either be approved for the position of community rabbi in Częstochowa, or receive a refund of the $60 \mathrm{zlp}$. he paid for his permit in 1830. He worked in Częstochowa until his death in 1871, and was indeed wealthy—he gave his son Szaja 3,000 złp. on the occasion of his marriage to Marianna Kohn in $1837 .{ }^{120}$

The Landau family also boasted a long pedigree. The father-in-law of Gedalja Tiktin, Wolf (Wolf Mojżesz) Landau (ca. 1744-1811), son of Abraham, was another Jew who bought a house in Częstochowa under Prussian rule. One of his brothers, Mojżesz Landau, was also active in the Jewish community; and his other brother, Chaim Mojżesz, was one of its founders (they may have been the same person). One of Wolf's sons was Abraham/Adolf Landau, who in 1829 married the daughter of Lewek (Leon) Kohn. Furthermore, the sons of Mojżesz were Natan Segal Landau, and the aforementioned Joachim/Nehemiasz (b. ca. 1805). The latter was a member of the "local clergy," 121 i.e. a rabbi. It seems that Rabbi Jonas did not belong to the Landaus of Częstochowa. Yet it is possible that he came from the Landaus of Opatów. Ezechiel Landau, a famous rabbi from Prague, came from this family, ${ }^{122}$ and other members thereof also worked in Szczekociny. ${ }^{123}$ Statements that Jonas was related to two-thirds of the Częstochowa inhabitants seem to be true, as the Landau family was the most numerous in the city at that time. The family was divided into groups, each with a nickname for distinction (Segal, Guttenteger, Kronenberg, Etengier, etc.). Merchant Józef Landau was the father-in-law of Izaak Feigenblatt, who married Freidla, the daughter of Lewek (Leon) Kohn, after the death of his first wife. Her sister Dobra was already married to Gerson Mojżesz Landau.

The next rich family from Częstochowa was the Kohns, whose primogenitor, Markus Lejbel Kohn, came into possession of a house and

${ }^{120}$ Ibid., Śluby [Marriages] 1837, p. 27. Jonas Landau, described here as "a rabbi of the Jewish faith.” Cf. AGAD, KWK, call no. 710; APŁ, RGP, call no. 2505, f. 214.

${ }^{121}$ Died in 1866 (Paszkowski, Cmentarz żydowski, 141). In Shatzky's opinion (Shatzky, "Jews in Czenstochowa," 30), he contributed to the publication Pirke avot in Krotoszyn in 1850.

${ }^{122}$ Hirsch Horowitz, "Die jüdische Gemeinde Opatow und ihre Rabbiner," Monatsschrift für Geschichte und Wissenschaft des Judentums 74 (1930), 1/2: 10-23; Gershon D. Hundert, The Jews in a Polish Private Town: The Case of Opatów in the Eighteenth Century (Baltimore-London, 1992), 159-160.

${ }^{123}$ The grandson of Yekhezkiel Landau, Jozue Segal (1778-1854), was born in Szczekociny. From 1806 to 1822, he was a rabbi in Pilica, then in Olkusz, and then from 1845 in Radom (Wodziński, Władze Królestwa Polskiego, 74-75). 
obtained the right to sell alcohol in the city during Prussian rule. By 1810 , he was the treasurer of the kahal. ${ }^{124} \mathrm{He}$ was also the father of merchant Berek Kohn, and Lewek (Leon) Kohn (ca. 1781-1845), who owned two houses and an inn at the end of his life. Lewek Kohn had many children, including sons Herz Naftali (ca. 1789-1862), ${ }^{125}$ Eicyk, and Maurycy (whose wife was Jetta Landau), as well as several daughters, three of whom married Landau men. The oldest son, Hertz, who became a landowner in Częstochowa in 1842, was a frequent member of the synagogue supervisory body. He was regarded as the leading Częstochowa progressive. ${ }^{126}$

The relationship between Lewek Kohn and the Landaus is thus plain to see, ${ }^{127}$ which suggests that it was precisely these families that supported Zachariasz Weingott in opposition to the Majzels and Ginsbergs in the dispute over the position of rabbi. Yet the family connections of Weingott himself do not clearly indicate his social background. He came from a very influential family in Kalisz, the voivodeship capital, where the community rabbi was Izrael Markus Weingott. ${ }^{128} \mathrm{He}$ had a large family, but most of his children married outside of Częstochowa. As we know, he was not at all a "backwards fanatic," but an Orthodox Talmudist familiar with new trends who had contacts in Silesia. In comparison with persons more closely related to Prussia, such as Mojżesz Majzel, he may have seemed like a guarantee of the preservation of tradition to the Orthodox majority. The Hasidim may have voted for him for this very reason. ${ }^{129}$ His candidature was likely supported by Auerbach, an influential teacher and rabbi from Łęczyca, as well as the family of Weingott's wife, the rabbinical Lewins-including his father-in-law, Efraim Beer, a rabbi in Koło with whom Weingott was closely associated. ${ }^{130} \mathrm{He}$ was also likely related to

124 AGAD, CWW, call no. 905, pp. 49-51.

${ }^{125}$ Cf. Testamenty, part 3 (Częstochowa, 2011), 139-144, 442-444.

${ }^{126}$ Shatzky, "Jews in Czenstochowa," 14-15. But it can be read in Jutrzenka (1862), 48: 408, that he gathered around himself others "of a similar conservative-progressive spirit."

${ }^{127}$ The first wife of Markus, one of Hertz Kohn's sons, was Fajgla Landau. The second was Estera, the daughter of Adolf Landau. The son of Wolf Landau, Pinkus, married Rezla, the sister of Berek Kohn, in 1808.

${ }^{128}$ AGAD, CWW, call no. 905. They are likely to be the same person, "Rabbinatspräses," who is mentioned around 1820 by Louis Lewin; see L. Lewin, Beträge zur Geschichte der Juden in Kalisch (Kempen, 1909), 22.

129 The accusation by "Bendawid," i.e. N. Landau, that Weingott was in 1839 supported by "zealots," i.e. Hasidim, is probably true only in this sense.

${ }^{130}$ In 1828, the daughter of Z. Weingott married Jakob Majer Lewi, son of Efraim Beer from Koło. 
Jakub Lewi, whose first wife was Dwora Lewin. ${ }^{131}$ It is important to note, however, that family obligations are not the only ones that bind social actors. Moreover, at least in the case of Częstochowa, family relations were not unambiguous, as everyone was tied to everyone else by marriage. ${ }^{132}$

The hypothesis that two rival camps were disputing the position of community rabbi in Częstochowa seems well grounded; yet a full picture requires analysis of the social changes that were taking place at the time. The first camp consisted of the Majzels and Ginsbergs, whose candidates for rabbi were J. Brass and M. Majzel; while the second consisted of the family of Lewek Kohn and his son Hertz, in association with the Landaus, whose candidates were J. Lewi and Z. Weingott. ${ }^{133}$ The origins of such a family arrangement in Częstochowa can likely be traced back to the end of the eighteenth century, when the local community was just beginning to form, and where the largest role was played by people who were legally entitled to residency and possession of real estate in the city. In the face of adverse surroundings, these families had to coexist, and share the majority of the burdens related to creating a community infrastructure. ${ }^{134}$ They also took for granted that they had the deciding voice in terms of electing community servants. Due to the costs involved, they were in no rush to hire a rabbi; however, for newly formed communities, having one was considered a symbol of independence. ${ }^{135}$ Sufficient for their purposes was Jakob ben Eliezer Lewi, who was formally hired as a municipal official, but who possessed rabbinical competencies. It was not until some dozen years later that Weingott, experienced as an assistant rabbi in Koło and author of two printed works, became rabbi. It is significant that he was nominated by the kahal, which due to state regulations ${ }^{136}$ was soon to be shut down. The kahal was composed of Lewek Kohn, Jakub Landau,

${ }^{131}$ It is difficult to determine the family relations of Jakub Lewi (as is the case with Jakub Brass) due to the lack of vital records before 1808 .

${ }^{132}$ For example, the Landaus with the Ginsbergs (the second wife of Majer Ginsberg, son of Berek, was Ruchla Landau; his sister Dobra married Natan Segal Landau in 1829).

${ }^{133}$ It is no coincidence that M. Weitzen, Icyk Frayman, and others protested the approval of Jonas Landau in a letter dated 4 October 1830. Frayman was the son-in-law of Berek Ginsberg, and appears in vital records as Weyzen. M. Weitzen was probably his brother.

${ }^{134}$ For example, the mikvah was funded personally by Wolf Landau, Markus Kohn, Lewek Kohn, Lipmann Heyman, and Józef Landau (Wodziński, Źródła, 58, 61). See Złotkowski, "Spór o dochody z propinacji," 511, 513ff.

135 Stampfer, Families, 302-323.

${ }^{136}$ The decree of Alexander I from 1 January 1822 on the liquidation of kahals was preceded by the decision of the Viceroy from 20 February 1821, and that of the Government Commission for Religious Denominations and Public Enlightenment from 24 April 1821. 
and Judka Reycher, where the last was the brother-in-law of the first. At that time, Weingott seemed a candidate in the same circle of Auerbach's pupils, who were close to the Tiktin family (just like Mojżesz Majzel). We do not know what forced Weingott to resign at a time when the supervisory body (appointed in 1822) was composed of Hertz Kohn, Lewek Likiernik, and Lipmann Heyman. Seemingly key is Heyman-a rich hat maker, homeowner since 1803, and large-scale supplier for the army under the Duchy of Warsaw and later. Born around 1770, Heyman belonged to the founding generation of the community, though his role in its formation was not particularly pronounced, possibly due to his line of work. However, from 1822 to 1836 , he was a member of the supervisory body. It was during this time that Weingott was forced to resign, and was twice denied re-election by the body. Only narrative sources like egodocuments could explain the intricacies of the "case of Zachariasz Weingott." Yet it seems reasonable to assume that representatives of two of the richest families, the Majzels and Ginsbergs, in an agreement with L. Heyman, ${ }^{137}$ decided dismiss Weingott, who was perhaps too independent, and unofficially entrust his obligations to Jakub Brass, who appeared to be a less expressive personality, and in turn to Mojżesz Majzel, an elderly man. However, there were many other disputes between individual members of the above-mentioned families; for example, that over the Jewish hospital building (which is well documented). ${ }^{138}$

Likewise, without additional sources, we can neither determine why Jakub Brass was entrusted with the obligations of the community rabbi (in the case of Majzel, family interests played an obvious role), nor who supported Weingott's installment and return, or for what reason and how long. Yet it is clear that each influential social group pushed for the installment of one of its own people as rabbi, in an effort not only to raise its own prestige, but to obtain favorable decisions. In the case of Częstochowa, it is possible to demonstrate a direct connection between rabbinical nominations and the close, clientele-type family influences which frequently occurred in Jewish communities. However, less has been written about this than about the inheritance of rabbi positions by sons or

${ }^{137}$ Whose family relations are unclear, as he started a family before 1808. After his first wife died, he married a widow named Rozla Tropplowicz from Silesian Biskupice.

${ }_{138}$ Which they purchased together in 1841. Later, Maurycy Kohn accused Majer Ginsberg of usurping the building, and Adolf Gerson Landau of improper management (APE, RGP, call no. 2506, pp. 95, 98; AGAD, CWW, call no. 1542, pp. 279-309). 
sons-in-law. ${ }^{139}$ Family interests were determined by a variety of motives, a closer analysis of which should be the subject of further study. The issue is complex, and must be considered in the context of the changing function of the rabbinate at that time. Sometimes seen as the period of its decline, the nineteenth century no doubt witnessed a weakening of the rabbinate in comparison with municipal lay authorities. ${ }^{140}$

Translated by Jack Ramsey Zagorski

Janusz Spyra Jan Długosz University in Częstochowa janusz.spyra@wp.pl

139 Stampfer, Families, 282-283, 302-323.

${ }^{140}$ Ibid., 282-295. 